\title{
A LINHAGEM CULTURALISTA DA SOCIOLOGIA DO FUTEBOL BRASILEIRO
}

\author{
Juliano de Souza \\ é professor associado do programa de pós-graduação em educação física da Universidade \\ Estadual de Maringá (UEM) e da Universidade Estadual de Londrina (UEL). Maringá, PR, Brasil. \\ E-mail: <julianoedf@yahoo.com.br> \\ http://dx.doi.org/10.1590/0102-103134/103
}

\section{Introdução}

Este texto recupera, expõe e atualiza parte das discussões de minha tese de doutoramento (Souza, 2014). A hipótese que aqui procuro desenvolver é que a leitura culturalista do futebol brasileiro, pensada, sistematizada e rotinizada no campo intelectual e nas demais esferas de produção cultural no país ao longo do século XX, tem pais e herdeiros, constituindo, portanto, uma "família intelectual". Inspirado assim no quadro teórico de Brandão (2005), construído na esteira do programa para a sociologia do conhecimento de Mannheim $(1967,1976)$, procuro restituir o "cordão invisível" através do qual autores e produtores culturais - de gerações distintas e tempos históricos diferentes - se apropriaram de uma série de ideias-força que, embora mobilizadas sob múltiplas roupagens teóricas em seus empreendimentos analíticos em relação ao futebol, e até mesmo com outras conotações, reportam a um núcleo argumentativo comum, a saber, que o futebol no Brasil é uma instituição social sui generis, supostamente apropriada de forma singular no país, proporcionando uma dinâmica de sociabilidade que se crê ímpar. 
É oportuno notar que, no exercício de desvelar como ideias-força desse tipo foram acionadas e articuladas no interior dessa "família intelectual", é prática rotineira atribuir ao antropólogo Roberto DaMatta o desenvolvimento de proposições inéditas e originais neste campo de estudo. No entanto, as coisas não ocorreram exatamente dessa forma, e o projeto de interpretar as relações estabelecidas entre futebol e sociedade brasileira no âmbito dessa linhagem encontra nos esforços de Gilberto Freyre e de Mário Rodrigues Filho suas bases primeiras de sustentação. Meu posicionamento, portanto, se assenta no entendimento de que DaMatta cumpre o papel de sistematizador dessas ideias, devendo a Freyre a maneira como interpreta a paisagem social brasileira e a Mário Filho o modo como concebe as relações raciais constituídas no âmbito do futebol.

Além de demonstrar a durabilidade histórica das ideias-força caras a essa "família intelectual", assumo também como 104 objetivos norteadores: (a) restituir algumas das particularidades analíticas dessa linhagem e (b) apontar alguns efeitos sociais da circulação de suas ideias na lógica de reiteração da identidade nacional. Para isso, divido o texto em três partes denominadas de atos. No primeiro ato revisito, em linhas gerais, o empreendimento fundador de Gilberto Freyre e Mário Filho no tocante à interpretação culturalista do futebol brasileiro. No segundo, recupero o modelo teórico de DaMatta e defendo o caráter sistematizador de suas análises no âmago dessa "família intelectual”. No terceiro, por fim, forneço algumas pistas acerca da rotinização da leitura culturalista do futebol no Brasil e sua repercussão naturalizada.

\section{Primeiro ato: fundação}

Conforme observo em minha tese (Souza, 2014), o fato de Gilberto Freyre ter sido um dos intelectuais mais geniais que a sociedade brasileira conheceu não impediu a recepção controversa de sua obra no meio acadêmico brasileiro. 
Ademais, poucos autores das ciências sociais no Brasil tiveram suas ideias tão duramente combatidas como Freyre. Dentre algumas das críticas mais contundentes endereçadas à sua obra destacam-se: (a) o desenvolvimento de um modelo teórico cuja aplicabilidade e alcance se limitaria apenas à região Nordeste do Brasil (Holanda, 1979); (b) a ênfase de suas análises apenas na escravidão doméstica, negligenciando, nesse particular, o trabalho escravo no eito e sobretudo na lavoura (Cardoso, 1962; Ianni, 1962); e (c) o caráter ideológico e mistificador de suas teses (Fernandes, 2008; Souza, 2006).

Sem dúvida, esse último aspecto crítico, dentre aqueles associados à obra freyreana, é o mais incisivo e polêmico no que se refere à divulgação e circulação de suas ideias no Brasil, até porque a denúncia do suposto caráter ideológico das teses de Freyre implica reconhecer ou ao menos cogitar que o autor não apenas construiu um modelo macroexplicativo da sociedade brasileira, mas um modelo que faz, e de certa forma refaz, essa realidade.

É importante ressaltar que Freyre, como outros autores clássicos do pensamento social brasileiro, também se propôs a pensar o processo de modernização da sociedade brasileira em termos de continuidade com Portugal. Em Faoro (1979), por exemplo, esse projeto foi levado a cabo na medida em que a experiência patrimonialista brasileira se fazia devedora da relação histórica mantida entre metrópole e colônia, ao passo que, em Holanda (1995), o chamado "homem cordial" e familisticamente emotivo teria sido formado com base na ordem cultural portuguesa. $\mathrm{Na}$ obra de Freyre, por sua vez, a noção de continuidade orgânica com Portugal foi pleiteada no propósito de explicar, por um lado, o encontro cultural das raças, favorecido pela suposta "plasticidade" do homem português e, por outro, para sustentar a centralidade da família tutelar na dinâmica estrutural e estruturante das relações políticas e culturais da sociedade brasileira (Souza, 2003). 
É oportuno reconhecer que o projeto freyreano de interpretação da paisagem social brasileira não foi construído ou pensado a partir das dinâmicas institucionais ancoradas no Estado, no mercado ou na Igreja. Dito de outro modo, a abordagem de Freyre se constituiu de forma contrária ao pensamento dominante da época na qual redigiu Casa-grande E $\mathcal{F}$ senzala e Sobrados e mucambos, de modo a não enfatizar o papel das instituições mencionadas na análise da sociedade supostamente singular que aqui teria se formado. Ao invés disso, o autor elegeu a família patriarcal - em seus termos, uma dessas "grandes forças permanentes" em torno da qual "os principais acontecimentos brasileiros giraram durante quatro séculos" (Freyre, 2003a, p. 78) - como elemento explicativo central de sua agenda. Em suma, a família tutelar, nessa arquitetura teórica, seria a base estrutural e emocional sobre a qual se organizou a vida política, social e cultural no Brasil.

106 Ademais, para Freyre (2003a, 2006), a constituição de uma família polígama em torno dos patriarcas decorreria da necessidade de ampliação do núcleo familiar, bem como do povoamento das terras. Paralelamente a essa leitura, o autor também ponderou que existiria uma perspectiva de mobilidade social para o negro no interior desse sistema, mobilidade esta que, em última instância, seria representada pela emergência da figura do mestiço resultante do "encontro afetivo" entre o senhorzinho e a escrava "fazedora de quitutes". A perspectiva de ascensão em meio a esse universo de contrastes, segundo Freyre (2006), teria sido garantida pelo fato de que muitos filhos mestiços foram educados no espaço da casa-grande com os filhos de nhonhô e iaiá, tendo, portanto, a real possibilidade de se tornarem legítimos ao se apropriar da cultura legítima em voga.

Há que se reconhecer que Freyre, ao inventariar essa gama de relações que, embora fossem hierárquicas - como ele próprio destacou ao longo de sua obra - também 
favoreciam uma espécie de camaradagem horizontal entre opostos, não as idealizava nem as retomava de forma essencialista. Em que pese, portanto, seu ecletismo metodológico, sua sensibilidade antropológica e sua recusa à divisão do trabalho intelectual, o autor também enfatizou em seus textos uma visão objetivista da sociologia. Em outros termos, Freyre não partilhou apenas de uma visão subjetivista do trabalho sociológico, que se centra somente em evocar a sensibilidade dos atores, haja vista que, ao tecer suas análises, levou em conta a existência de um complexo estrutural que suportaria os raios de ação e comportamento de personagens ideais típicos - complexo estrutural representado esquematicamente pela "casa-grande" e o "sobrado", acompanhados de seus correspondentes "senzala" e "mucambo".

Por sinal, na introdução à segunda edição de Sobrados $e$ mucambos, Freyre (2003a, p. 91) diz não conhecer símbolos mais adequados que "casas-grandes e senzalas" e "sobrados e mucambos" para explicar a expansão do sistema patriarcal no Brasil e as diferenças de status entre as personagens centrais de sua trama, isto é, o senhor branco e o escravo negro. Ao reconstruir o "todo socioestrutural significativo" da economia patriarcal brasileira, Freyre, como assevera Cardoso (2006, p. 21), recorreu à esfera íntima, sexual e afetiva, tomando os comportamentos em seu núcleo de ação efetivo, e não apenas como padrões culturais. Esse tipo de reconstrução, por sua vez, foi garantido na obra do autor na medida em que a estrutura da "casa-grande e senzala" noutro momento, de "sobrados e mucambos" - funcionaria como mecanismo regulador tanto da vida quanto da personalidade dos brasileiros (Souza, 2014).

Com todo o risco de ter fornecido uma visão teórica simplificada e mesmo incompleta da arquitetura teórica mobilizada pelo sociólogo, é oportuno ressaltar, à maneira de síntese, que a tese da miscigenação e da democracia racial são as principais ideias-força de seu modelo interpretativo 
da formação social brasileira, posteriormente sendo solicitadas pelo autor (e por outros autores que o sucederam) para pensar o papel e valor do futebol no Brasil. Em outras palavras, Freyre priorizou em sua leitura da formação societária brasileira o encontro cultural das raças e a perspectiva de mobilidade social para os negros, estando essas duas dimensões intimamente concatenadas em suas análises.

Essas duas dimensões são acentuadas pelo próprio Freyre ao pensar a suposta singularidade do futebol brasileiro, conforme documentam estudiosos que se dedicaram a reconstituir e problematizar a interpretação do sociólogo acerca dessa prática esportiva trazida de terras inglesas (Barreto, 2004; Capraro, 2011a; Maranhão, 2006; Morais e Ratton Júnior, 2011; Soares, 2003). Estariam postas, nesse caso, as bases teóricas que levaram Freyre a pensar o futebol brasileiro como uma variante sui generis e sem equivalentes no mundo, ou seja, estabelecido enquanto tal basicamente 108 por conta da híbrida gramática social que haveria favorecido uma apropriação cultural distinta da prática esportiva no país. Ao saudar o pioneirismo de Freyre nos estudos sociológicos do futebol no Brasil, DaMatta indaga:

Haveria, neste uso exclusivo dos pés que caracteriza o football association, uma relação inconsciente com o jogo de capoeira que os escravos africanos trouxeram para o Brasil? Jogo onde as armas de luta não são os punhos, mas os pés? Gilberto Freyre, que é o único dos interpretes clássicos da sociedade brasileira a tocar no futebol, responde afirmativamente, salientando no famoso cap. XI de Sobrados e mocambos que o pé pequeno do mulato brasileiro ajudava os passos rápidos tanto do samba quanto da capoeira. Samba que o levava para dentro do sistema como dançarino alegre, capoeira que o marginalizava e sinalizava seu lado rebelde. Ambos, contudo apaziguados, como remarca Gilberto Freyre, pelo futebol "dionisíaco" - esse instrumento privilegiado de ascensão do 
negro e do mulato dentro da sociedade brasileira. O fato é que esse jogo britânico do "pé na bola" foi reinterpretado no Brasil como a arte da "bola no pé", o que mudou tudo. Num caso a bola é um atrapalho a ser rebatido, despachado ou chutado com o pé que, afinal, foi feito para isso mesmo; no outro, entretanto, descobre-se uma afinidade inusitada entre o pé e a bola que agora tem com esse pedaço do corpo humano uma séria afinidade e atração que é uma das marcas mais importantes do futebol brasileiro. Pois por meio dele e, acima de tudo, com ele, a bola transforma-se em objeto feminino e desejável, e o pé transforma-se em instrumento que segura, prende, acaricia, domina, controla, prende e "come" a bola (DaMatta, 2006, p. 157).

Esse excerto é revelador de que DaMatta estabelece interlocução com Freyre de modo a conferir legitimidade a suas explicações sobre a recepção do futebol no Brasil, marcado, no entendimento dessa "família intelectual", por uma reapropriação cultural distinta, que culminaria na invenção de um estilo brasileiro de praticar o esporte e, assim, na emergência do "futebol-arte". No entanto, esse tipo de posicionamento, antes de DaMatta, já se fazia presente - com algumas ressalvas e especificidades - em $O$ negro no futebol brasileiro, de Mário Rodrigues Filho.

A primeira versão de $O$ negro no futebol brasileiro foi publicada em 1947, e sua estrutura original era composta de quatro capítulos. Em 1964, Mário Filho acrescentou dois novos capítulos ao livro, que assim tomou sua forma definitiva. De um modo geral, o texto se caracteriza como uma narrativa histórica do futebol brasileiro (tendo como ponto de partida a trama social específica ao futebol carioca) endossada por uma infinidade de arranjos sociais recuperados pelo autor através de pesquisa em atas, súmulas, jornais, álbuns e, principalmente, por via de uma tradição oral atenta a fatos não registrados nas fontes oficiais, 
de forma a potencializar o descortinamento de alguns processos esquecidos ou ocultados na história do futebol brasileiro e em sua construção historiográfica (Rodrigues Filho, 2003, pp. 20-23).

Se não bastasse essa variedade de fontes históricas que o qualificam, o livro de Mário Filho ainda fornece pistas sociológicas importantes sobre a formação da sociedade brasileira, em especial no que diz respeito à construção de uma identidade nacional compartilhada (da qual a própria obra em tela é depositária e refratária), alavancada na ideia da mestiçagem como característica virtuosa do povo formado aqui nos trópicos. Além disso, uma leitura mais cuidadosa do livro mostra que Mário Filho problematizou uma série de mecanismos de mobilidade social presentes na sociedade brasileira, assim como as distâncias e barreiras raciais e sociais erguidas como critérios estruturantes da ação e como pressupostos valorativos que classificam os indivíduos e os 110 grupos sociais no Brasil (Souza, 2014).

Entre as influências teóricas que nortearam Mário Filho na escrita de seu texto, se encontram, como já afirmei, as formulações clássicas de Freyre e o debate racialista em voga entre a intelectualidade nacional do período (Souza, 2014). Cabe frisar, quanto à alusão de Mário Filho às ideias freyreanas, que a academia não tem dificuldades em reconhecer esse fato e tecer suas considerações (Capraro, 2011a, 2011b, p. 218; Soares, 2003). O próprio prefácio escrito por Freyre para a primeira tiragem do livro, ou mesmo o reconhecimento implícito dessa filiação por Mário Filho na nota à primeira edição, bem como uma série de argumentos que percorrem e se repetem por todo o livro são bons indicativos da conjectura que estamos tecendo. Excertos como os que seguem não me deixam mentir:

Falar em futebol era falar na derrota do Vasco. Veio outra semana, o Vasco continuou a vencer, não perdeu mais até 
o fim do campeonato. A vitória do Flamengo tinha dado a ilusão de que tudo ia voltar a ser o que era dantes, os times de brancos sempre levantando campeonatos, os times de pretos perdendo sempre. A ilusão durou pouco, os clubes finos, de sociedade, como se dizia, estavam diante de um fato consumado. Não se ganhava campeonato só com times de brancos. Um time de brancos, mulatos e pretos era campeão da cidade. Contra esse time, os times de brancos não tinham podido fazer nada. Desaparecera a vantagem de ser da boa família, de ser estudante, de ser branco. O rapaz de boa família, o estudante, o branco, tinha de competir, em igualdade de condições, com o pé-rapado, quase analfabeto, o mulato e o preto, pra ver quem jogava melhor. Era uma verdadeira revolução que se operava no futebol brasileiro. Restava saber qual seria a reação dos grandes clubes (Rodrigues Filho, 2003, p. 126).

Porque com o profissionalismo não fazia mal o Fluminense botar um mulato, um preto no time, contanto que fosse um grande jogador. Melhor branco. Mulato ou preto, só grande jogador (Rodrigues Filho, 2003, p. 193).

Ameaçado de perder seus amadores, os seus brancos, o Botafogo foi para cima dos jogadores dos outros clubes, sem ligar mais à cor. Tirou Leônidas do Vasco, Waldemar do São Paulo. Pouco importava que fossem pretos. Eram pretos, mas eram os maiores atacantes do futebol brasileiro. Assim não faziam mal, só podiam fazer bem (Rodrigues Filho, 2003, p. 205).

Mas o Flamengo ainda não era um clube do povo. Fazia a mesma questão de cor do Fluminense. Virou clube do povo quando acabou com a estória de só branco no time. Abrindo a porta da Gávea para os pretos (Rodrigues Filho, 2003, p. 210). 
Mário Filho corrobora a tese da democracia racial nesses excertos, na medida em que narra a ascensão social de negros e mestiços nos quatro principais clubes cariocas, sendo o Vasco da Gama o pioneiro nessa iniciativa ao ganhar o campeonato estadual de 1923 com negros, mulatos e pobres compondo seu escrete, ao passo que nos outros três grandes clubes essa experiência só se concretizaria quase uma década mais tarde, a partir dos anos 1930. É sempre importante frisar que por trás desse tipo de narrativa subjaz a ideia de que o futebol - na condição de microcosmo social dotado de pouca autonomia, ao menos a partir do ponto de vista teórico culturalista - refletiria um movimento de democratização racial operado mais amplamente na sociedade brasileira como um todo.

Ademais, Mário Filho - conforme analisei com maior profundidade na pesquisa que dá origem a este texto (Souza, 2014) - estabelece uma tentativa de correspondên112 cia entre miscigenação racial - a suposta "reapropriação cultural dionisíaca" que se operou no futebol brasileiro por conta dos negros e mulatos que o praticavam - e a ascensão social das populações de cor no contexto futebolístico nacional, instituindo uma dinâmica analítica particular que aos ouvidos de Freyre parecia soar como música, como ele mesmo reconheceu: "era natural que o futebol, no Brasil, ao engrandecer-se em instituição nacional, engrandecesse também o negro, o descendente de negro, o mulato, o cafuzo, o mestiço" (Freyre, 2003b, p. 25).

\section{Segundo ato: sistematização}

Como argumentei até aqui, a leitura culturalista do futebol brasileiro teve sua gênese em Freyre e Mário Filho. A partir de agora, demonstrarei como DaMatta deu continuidade a esse empreendimento, tornando a tese da democracia racial mais dialógica e reconvertendo-a na tese da democracia social. Vale pontuar então que DaMatta, assim como 
Freyre, não elegeu o Estado, o mercado ou a Igreja como pontos de partida para suas reflexões, cujo propósito maior seria trazer à tona "o que faz o brasil, Brasil". Ao invés disso, em seu clássico livro Carnavais, malandros e heróis, publicado originalmente em 1979, DaMatta procurou acessar o universo social brasileiro e interpretá-lo a partir de alguns de seus principais ritos: o carnaval, os desfiles cívicos, o futebol etc. (DaMatta, 1997).

Para levar com rigor seu projeto de compreender os caminhos que tornam a sociedade brasileira única e singular, DaMatta se vale de um rigoroso esquema conceitual no qual as noções de "indivíduo" e "pessoa" merecem maior atenção, porque são justamente esses elementos que dão suporte ao desenvolvimento da categoria "dilema brasileiro" ou "jeitinho brasileiro". A inspiração dumontiana, nesse quesito, é particularmente visível. Note-se que "indivíduo", para DaMatta, trata daquele sujeito fruto do liberalismo, que se conforma aos ideais de mercado e age impessoalmente segundo as regras que governam a vida moderna, ao passo que a "pessoa" seria aquele tipo de sujeito que age amparado em favores e camaradagens provenientes de seus núcleos de contatos íntimos e pessoais, algo típico de um contexto de ação social pré-moderno ou tradicional (DaMatta, 1997).

O "dilema brasileiro", nesse sentido, é mobilizado por DaMatta para sintetizar o fato de que, no Brasil, haveria um predomínio das relações pessoalistas sobre as relações impessoalistas, dos comportamentos típicos da casa sobre os comportamentos típicos da rua. Prova disso, dentre outras coisas, seria o rito verbalizado do "Você sabe com quem está falando?", constantemente evocado na vida pública brasileira (ainda que os indivíduos que se valham do rito sintam-se comumente embaraçados por isso) para restabelecer ou reforçar as hierarquias tradicionais por conta de se pertencer a determinada família de influência na sociedade ou então por se ter um primo político etc. Nos Estados Unidos, por 
sua vez, quando os indivíduos se deparam com uma situação conflituosa, recorrem, com vistas a estabelecer a igualdade, ao rito "quem você pensa que é?” (DaMatta, 1997, p. 197).

É sobre essa ótica específica, segundo Souza (2001), que DaMatta procura ensaiar uma explicação sui generis para a desigualdade brasileira, muito embora sua preocupação maior seja trazer à luz aqueles elementos que contribuíram para a conformação de um tipo singularmente cultural de sociedade, que só poderia ser desvelado quando visto de forma positiva, otimista, e não a partir da hipótese negativista do atraso. Não é por acaso, portanto, que DaMatta elege o carnaval, o jogo do bicho, as procissões religiosas, as paradas cívicas e especialmente o futebol como chaves interpretativas para avançar em seu empreendimento.

É necessário frisar que esses objetos eleitos pelo autor se situam no domínio do mundo social extraordinário, ao passo que as rotinas de seriedade são encaradas como per114 tencentes ao raio de ação do mundo social ordinário. De acordo com o autor, é no domínio do mundo social extracotidiano que o Brasil se revela e, portanto, permite-se ler como sociedade, pois nesses momentos é que seriam dramatizadas, sob a forma de ritos, as principais características estruturais e afetivas que orientam nossa sociedade em seu cotidiano (DaMatta, 1997).

Os ritos pensados e estudados em suas manifestações coletivas por DaMatta (1997) preencheriam algumas funções nesse tipo de formação social e, para tanto, se classificariam do seguinte modo: (a) ritos de reforço que reiteram a estrutura e a hierarquia de poder; (b) ritos de inversão, nos quais os papéis sociais são invertidos de modo a propiciar, no plano mimético, uma experiência de igualdade, justiça e democracia; e (c) ritos de neutralização, nos quais se verifica uma alternância entre as duas primeiras tipologias de ritos. Sendo assim, o rito emerge como categoria heurística na abordagem damattiana, já que é pela dramatização 
inerente ao rito que os homens "tomariam consciência das coisas" e então passariam a "vê-las como tendo um sentido, vale dizer, como sendo sociais" (DaMatta, 1997, p. 36). É, portanto, no lastro desse esquema exposto que o autor teoriza sobre o futebol.

Cabe notar que o futebol brasileiro, em DaMatta, é exclusivamente interpretado como um rito de inversão que denota um "drama por justiça social" e, em seguida, como um rito de reforço que fortalece os vínculos e sentimentos nacionais. É importante considerar que esse tipo de diagnóstico está presente em vários textos de DaMatta (1982a, 1982b, 2003, 2006), reiterando, ao longo do tempo e de sua obra, a ideia do futebol como uma "escola da vida" ou "aula de democracia":

No futebol e pelo futebol, o povo aprendeu que pode vencer seus problemas sem salvacionismos messiânicos ou ideológicos. Com ele, o Brasil teve uma grata e apaziguante experiência com a vitória, com a excelência, com a competência, com a paciência e com o amor, esses valores sistemática e significativamente ausentes dos projetos políticos. Nesses papéis, ao contrário do futebol, a sociedade brasileira surge como uma entidade vazia de valores, destinada a ser reeducada e transformada pelo Estado. É, pois, o futebol que engendra essa cidadania positiva e prazerosa, profundamente sociocultural, que transforma o Brasil dos problemas, das vergonhas e das derrotas, no país encantado das lutas, da competência e das vitórias. Uma coletividade que pode finalmente contar com suas próprias forças e talento. Com o futebol, o Brasil não nos enche de vergonha - como ocorre no discurso dos políticos -, mas de orgulho, carinho e amor. Viva o carnaval! Viva o futebol! E viva o povo brasileiro que generosamente permite que o Brasil campeão resgate o Brasil que tem ódio de si mesmo (DaMatta, 2006, p. 124). 
Como exemplarmente revela o excerto, DaMatta eleva o futebol ao nível de fenômeno quase etéreo, que permitiria à sociedade brasileira acertar as contas com ela mesma. Para o autor, o futebol, assim como o carnaval, inverteria uma ordem social repleta de injustiças, dissolvendo, mesmo que por um instante, as distâncias objetivas que se construíram no Brasil em termos de classe, raça, religião etc. Além disso, pelo futebol, a população brasileira teria uma possibilidade real de se descobrir mais alegremente como parte de uma coletividade, encontrando uma fonte de energia para voltar ao cotidiano. Desse modo, o futebol seria importante

não porque ele faça esquecer as mazelas e as mistificações rotineiras, mas porque a experiência com a vitória, com a excelência, com o esforço e o sacrifício coletivos, com o entregar-se de corpo e alma a uma camisa-causa, permite voltar ao trabalho com novas disposições (DaMatta, 2006, p. 126).

Em suma, o argumento de DaMatta é que o futebol em particular e o esporte em geral trouxeram em si, num primeiro momento, os germes de uma lógica individualista moderna, por se tratarem, a rigor, de fenômenos de origem inglesa que remontam à metade final do século XIX. Num segundo momento, por sua vez, essas práticas - ao serem contrastadas com uma sociedade como a brasileira, marcada pelo predomínio de relações pessoalistas e pela troca de favores, onde só teriam vez os poderosos - produziram, por meio de um rito de inversão, uma experiência singular de democracia e igualdade. Aí residiria, para DaMatta, a explicação de o futebol ter se popularizado de forma transclassista no Brasil.

Com relação aos pressupostos teóricos que subjazem a essa proposta interpretativa da relação entre futebol e sociedade brasileira, colocada em termos quase endêmicos, para não dizer endógamos, DaMatta (1982b, p. 55, grifo meu) argumenta que: 
A questão está em descobrir que vivemos numa sociedade que relaciona intensa e funcionalmente dois sistemas: um de mercado, acoplado a um aparato legal, fundado em leis universais e no indivíduo como sujeito; e outro, de redes imperativas de relações pessoais, que funcionam hierarquicamente, mantendo os velhos privilégios elitistas. O problema não seria ter capitalismo em excesso mas ter capitalismo pela metade. Isto é, um sistema onde o mercado e as leis universais somente operam para baixo, no sentido dos que não têm uma representatividade por meio do nome, das relações ou dos bens de família. A raiz do nosso autoritarismo, deste modo, estaria nesta simultaneidade ou nesta capacidade de relacionar laços de família, amizade e compadrio [...] e um sistema de leis universais que são constantemente colocadas em xeque pela lógica dos laços pessoais. Penso que é neste quadro social que poderemos interpretar a popularidade e a importância de um esporte como o futebol.

É importante atentar ao fato de que o que DaMatta chama de "quadro social", com vistas a conferir maior credibilidade a seu modelo, não se trata propriamente de um quadro social, mas de um quadro teórico sob o qual ele mesmo e seus continuadores se incumbiram de ler o futebol brasileiro. Trata-se de um quadro teórico personalista que, em certa medida, foi prenunciado em Freyre, Holanda e, no caso específico do futebol, em Mário Filho. É desse quadro teórico, portanto, que emanam as categorias das quais DaMatta se vale, sob uma roupagem híbrida, para interpretar o futebol brasileiro e outros fenômenos culturais à luz das supostas "especificidades" dessa formação social, antevistas teoricamente pela geração da qual ele é o porta-voz mais influente.

Outro aspecto a ser pontuado quanto à proposta de tratamento sociológico do futebol em DaMatta, é que o autor - apesar de reconhecer a importância de desenvolver 
um modelo teórico cujo pressuposto principal fosse encarar esporte e sociedade como "duas faces de uma mesma moeda e não como o telhado em relação aos alicerces de uma casa" (DaMatta, 1982a, p. 23) -, acaba muito mais realizando leituras dessa prática esportiva segundo os princípios supostamente estruturantes da dinâmica das relações sociais no país do que propriamente ler a sociedade brasileira por via dessa prática esportiva ou então procurar estabelecer uma postura mais relacional nesse exercício, conforme ele mesmo recobrou.

Independentemente, no entanto, dos diferentes níveis de articulação entre dimensões micro e macrossocial remetidos pelo modelo, o que insurge de mais relevante para argumentação que estou desenvolvendo é que as ideias damattianas, incrustadas ao propósito de recompor as singularidades nacionais, influenciaram a leitura que não somente uma geração seguinte de estudiosos faria sobre o futebol brasileiro, mas também as leituras que a imprensa esportiva 118 seja ela escrita ou televisionada -, os campos de produção cultural e o próprio senso comum retroalimentado pelo ofício desses especialistas da cultura teceriam e imporiam acerca da circulação dos bens e das práticas futebolísticas no Brasil. Uma das consequências sociais mais marcantes desses esforços conjuntos historicamente datados foi a construção de uma percepção hegemônica do futebol brasileiro que favoreceu a invisibilização e o ocultamento de uma série de contraprocessos atuantes no contexto de ação futebolístico (Souza, 2014).

\section{Terceiro ato: rotinização}

A partir do início dos anos 1990, vários pesquisadores das mais diferentes áreas se dedicaram ao estudo do futebol no país a partir de um ângulo sociocultural, produzindo trabalhos que, em alguma medida, foram influenciados pelas ideias-força de DaMatta. Uma variedade de exemplos poderia ser citada, mas não havendo espaço para tanto nesta ocasião, 
elegi para essa interlocução crítica os textos mais expressivos de Luiz Henrique de Toledo e Arlei Sander Damo.

Cabe inicialmente esclarecer, antes de retomar a título ilustrativo alguns dos aspectos desses textos, que esses interlocutores, apesar de muitas vezes se reportarem de forma crítica ao modelo teórico de DaMatta, ainda permanecem presos a algumas de suas ideias por duas razões íntimas: (a) porque tais autores, talvez pela falta de um distanciamento maior em relação ao referido modelo e suas implicações epistemológicas e sociais, reatualizaram as categorias damattianas no próprio ato de questioná-las; (b) porque mesmo se valendo das contribuições de toda uma literatura da vanguarda sociológica e antropológica internacional para trilhar caminhos teórico-metodológicos alternativos, no final das contas, tais estudiosos apresentaram conclusões muito próximas às de DaMatta.

Em Toledo (2000a, 2000b, 2008), percebo sua participação no modo de pensar da linhagem culturalista na medida em que pleiteia um acesso estruturalista e totalizante ao contexto de ação futebolístico brasileiro como um lócus de "significações flutuantes". Tais significações, por conseguinte, seriam motivo de restituição por parte do investigador social de modo a trazer à tona as expectativas que atores de diferentes segmentos e níveis de envolvimento com o futebol constroem nessa prática, ou seja, considerando a forma como vivem e a interpretam em seus campos de ação (Guedes, 2003).

$\mathrm{Na}$ esteira dessa análise, vale então ressaltar que, para Toledo (2000a, 2000b), variados contextos de apropriação do futebol produziram técnicas corporais diferenciadas por conta da variação na interpretação e aplicação das regras do futebol. É, inclusive, desse ponto de partida que o pesquisador procurou interpretar o "estilo futebolístico brasileiro", devedor, segundo ele, à heterogeneidade étnico-social e ao processo de resistência das populações negras na formação societária brasileira (Toledo, 2000b, p. 34). 
Como discuti com mais rigor em outro momento (Souza, 2014), esse tipo de explicação veio a ser aprofundada no modelo das "formas-representações" (Toledo, 2008), no qual o conjunto de regras preestabelecidas (igualitárias e universais), as formas (performances corporais treinadas) e as representações, numa espécie de relação interativa (de contiguidades e oposições) que envolve vários atores (profissionais, especialistas, torcedores), acabariam por definir estilos de jogo específicos, como o brasileiro ou europeu, ou o jogar à la Corinthians ou Grêmio (Toledo, 2000a). As passagens que seguem remetem bem ao modelo:

Nos treinos, observa-se, portanto, um embate dinâmico entre os atores - torcedores reivindicando gols e melhor aprimoramento das performances dos atletas, especialistas tentando desvendar os "segredos" dos times através do trabalho das comissões técnicas e dos próprios jogadores, e estes últimos, os profissionais, buscando uma forma ou padrão que, se consolidado com sucesso em campo, atingirá, no plano simbólico, às representações do jogar, referendadas por todo um socius (Toledo, 2000a, p. 163, grifos do autor).

Espera-se de qualquer jogador, na apreciação de suas qualidades sensíveis, estilo e técnica, ou dos técnicos, no exame dos "segredos" e "filosofias" de seu jogo, os padrões ou formas por eles experimentados, certas compatibilidades com as representações já inscritas e muitas vezes consolidadas no imaginário coletivo torcedor e propagado pela imprensa esportiva. Assim, um atleta ou até mesmo um técnico de um time como o Corinthians ou o Grêmio, por exemplo, deveriam jogar ou propor formas de jogo onde a garra, a vontade, a luta, independentemente das suas qualidades profissionais, capacidade, posição, função ou atribuições táticas pré-determinadas, sejam contempladas (Toledo, 2000a, p. 165, grifos do autor). 
Desse modo, as representações de estilos e formas de jogo se conformam de modo preexistente ao raio de ação primária dos atores, sejam eles torcedores, profissionais ou jornalistas. Nesse sentido, o esforço desses agentes consiste em se movimentar "ativamente", "voluntariamente", ou mesmo sem o saberem, de acordo ou desacordo com essas representações instituídas no imaginário coletivo. $\mathrm{O}$ modelo estrutural em tela conduz, portanto, à sensação de que as representações se impõem como realidade objetivamente externa que constrange os atores sociais. Em outras palavras, o modelo supõe que os atores se arranjam e desarranjam no âmago do fenômeno futebolístico brasileiro, como marionetes relativamente presas à "regra de ouro" reivindicada sob o estatuto de "lógicas do futebol". A assertiva que segue é esclarecedora dessa proposta:

Portanto, poderia afirmar que se trata não tanto de ler o Brasil pelo futebol, como se ele fosse uma autorrepresentação a-histórica, num sentido estrutural, mas ler também o futebol pela sociedade brasileira, nas suas múltiplas dimensões, identificadas, de um ponto de vista típico-ideal, na atuação dos especialistas, profissionais e torcedores que, por sua vez, investem, nem sempre de maneira consensual, na promoção e consolidação de nossa autoimagem, representada na englobante expressão Futebol Brasileiro (Toledo, 2000a, p. 31, grifo do autor).

Algumas questões imediatamente insurgem desse excerto: que sociedade brasileira é essa que Toledo chama à existência para ler o futebol? Que representações foram produzidas e têm sido atualizadas e reinventadas não só por profissionais, especialistas e torcedores, mas também pelos próprios intelectuais, acerca da sociedade brasileira e da função social que os bens esportivos e culturais exercem no país? Quais os inconvenientes de ler o futebol a partir de um consenso social teoricamente orientado, através do qual 
se reproduziu uma "ilusão compensatória" de singularidade apesar de todos os problemas?

Parar clarear esse quadro e lançar luz a essas questões é importante ressaltar, na esteira da análise proposta por Jessé de Souza (2006), que o personalismo e o patrimonialismo, em suas versões "puras" ou "híbridas", têm colonizado a percepção que a sociedade brasileira conserva dela mesma, tanto no campo acadêmico quanto no âmbito do senso comum. Para esse autor, se no patrimonialismo veicula-se uma interpretação pseudocrítica da realidade brasileira, no personalismo institui-se uma verdadeira aversão aos conflitos (Souza, 2003, 2006). Como diz DaMatta (2004, p. 28) ao rebater a tese do futebol como "ópio do povo": "Só se pode mudar aquilo que se ama. Eu achava que a teoria do "quanto pior, melhor' para mudar o Brasil não era uma boa teoria. A teoria para mudar o Brasil é quanto melhor fazemos e sentimos que as coisas melhoram, mais queremos mudar".

122 Por essas e outras razões, sempre ocultas e nunca devidamente tematizadas, é que a linhagem culturalista da sociologia do futebol atribui um valor residual aos conflitos sociais. Toledo envereda por esse olhar culturalista reticente aos conflitos quando alude à transição do futebol amador para o profissional no Brasil em seu livro No país do futebol:

A distinção social foi paulatinamente transfigurada em símbolo de um processo de identificação de nacionalidade experimentado pelos mais variados grupos sociais em todo o país. Futebol: símbolo brasileiro que ultrapassa as fronteiras nacionais, tal como se nota através da notoriedade alcançada por inúmeros jogadores, sobretudo Pelé, que condensa na imagem de "atleta do século" o estilo brasileiro de jogar (Toledo, 2000b, p. 9, grifo meu).

Toledo não chega ao ponto de dizer que no futebol vivenciamos uma experiência sem equivalentes de democracia, muito embora entenda que a distinção social foi 
reconduzida na transição do amadorismo para o profissionalismo de modo que, no lugar dela, segundo seu entendimento, passou a atuar um vínculo de solidariedade nacional reforçado, dentre outros meios, por via da modalidade do "futebol-arte" - categoria nativa instável da qual Toledo se vale, respaldado na voz dos atores que pesquisou, para explicar (a) as formas de jogo que se adaptariam ou não às enunciações; (b) as cobranças e motivações dos torcedores guiadas por esse nível de interação simbólica; e (c) as análises tecidas pela imprensa esportiva especializada no sentido de preservar esses códigos ou deles destoar.

$\mathrm{Na}$ continuidade de construção desse percurso, outro autor que - resguardados todos os avanços que seus investimentos representam para a sociologia do futebol brasileiro - também participa, em alguma medida, do modo de pensar caro à "família intelectual” em tela neste artigo é Arlei Damo. Tanto em sua dissertação de mestrado quanto em sua tese de doutorado (Damo, 1998, 2005), o autor menciona a existência de um "estilo futebolístico brasileiro" que, para além de suas aparentes e/ou possíveis funções ideológicas, açambarcaria elementos materiais e simbólicos manifestos sob a forma de habitus constituídos a partir do encontro conflituoso entre, de um lado, o nacionalismo e, de outro, o regionalismo.

Para Damo (2005, p. 335), "A originalidade do estilo brasileiro, habitus constituído a partir do arranjo entre a cultura futebolística e as culturas locais, só é eficaz na medida em que estão dadas as condições sociais para que ele seja aprendido e aperfeiçoado". Nesse particular, o "estilo futebolístico gaúcho" se constituiria por referência e oposição ao estilo brasileiro de "futebol-arte", ao passo que este último se constituiria também por referência e oposição ao "futebol-força" europeu. A materialização desses estilos ou sua corporificação se deve, para Damo, ao fato de as condições sociais (no caso de Toledo, as representações) estarem postas e serem acionadas de modo consciente ou 
inconsciente pelos atores. Esse tipo de "solução teórica" antevista faz toda diferença em seu argumento, tal como revela o excerto a seguir:

O público aplaude e vaia determinados gestos, individuais e coletivos e, assim sendo, marca sua disposição estética e, acredita-se, isso interfira nas ações dos jogadores que, por certo, preferirão, sempre que possível, os aplausos e, portanto, a realização de movimentos apreciados pelo público. Que isso não seja um processo mecânico é mais fácil de demonstrar teoricamente do que através de elementos etnográficos. Como disse anteriormente, os dados já haviam sido lançados quando estava em campo, razão pela qual decidi seguir em frente, indagando, aqui e ali, pelo tal de futebol-arte, um pouco como Quesalid, o cético aprendiz de feiticeiro que, no intuito de desmistificar a magia acaba mistificado por ela - Quesalid é personagem de Franz Boas, mas ficou famoso através de Lévi-Strauss (Damo, 2005, p. 325).

Há que se indagar, nesse sentido, a inexistência de uma crítica à dimensão da doxa, por exemplo ao problematizar - como o faz Bourdieu (1989), um autor importante em seu argumento - porque o mundo social se constrói de uma determinada forma, e não de outra qualquer. Em vez disso, Damo $(1998,2005)$ substitui essa preocupação com a maneira pela qual se naturaliza a identidade nacional através do futebol pela temática das identidades regionais, no sentido de apontar que estas talvez sejam mais decisivas e fortes para o entendimento do "fascínio coletivo" que o futebol alcançou no país.

Para levar adiante esse escopo, Damo (1998, p. 192) sugere certa vulnerabilidade da "identidade futebolística brasileira", de modo a garantir um espaço sobre o qual se assentariam as diversidades regionais, étnicas e raciais. Desse 
modo, o que estaria em jogo em sua análise não se resume somente ao desvelamento de um futebol unitário marcado por um "único estilo", seja nacional ou regional, mas no tratamento daquilo que veio a ser denominado pelo autor na condição de "futebóis", ou seja, práticas futebolísticas endossadas por inúmeras significações e estilos que se devem tanto às técnicas corporais em voga quanto ao ethos de cada uma das comunidades a que dizem respeito (Damo, 2005).

No lastro dessa argumentação, o autor ainda sugere que o futebol se divide em quatro matrizes: a bricolada, a espetacularizada, a escolar e a comunitária. Aqui importa se voltar por um instante à matriz bricolada, até porque, no intuito de compreendê-la, Damo (2005) parece atribuir um tratamento positivo à dimensão da "rua", originalmente vista no arcabouço teórico de DaMatta como o reino da impessoalidade, da competição e, portanto, da "negatividade da vida". Ao etnografar os meninos e meninas praticantes dessa variante de futebol em um bairro de classe média baixa da cidade de Porto Alegre, Damo tece as seguintes considerações:

O prazer estético dado pela ressemantização dos sacos de lixo, da bola murcha, das traves com sacos de folha secas, pelo jogo jogado no paralelepípedo, em meio aos carros estacionados, sem o calçado adequado, enfim, todos esses ingredientes de bricolagem característicos das peladas da Leão XIII poderiam ser tomados como signos que denotam um estilo de vida e mesmo uma representação de mundo. Todos os elementos referidos poderiam também ser tomados como indicativos das carências brasileiras, da falta de equipamentos adequados ao lazer, aos direitos das crianças e adolescentes, mas eles não são apenas isso. São, em certo sentido, intencionalmente engendrados, incorporados ao jogo e até mesmo imprescindíveis a ele, na medida em que constituem-no como verossímil em 
relação às representações generalizadas de que é assim que se aprende a jogar futebol "à brasileira” ou, como é definido entre nós, é assim que se faz o futebol-arte. A arte residiria, precisamente, na capacidade de contornar o incontornável, no jogo de cintura, no bricolar com o corpo, com a moralidade, a estética e assim por diante. $\mathrm{O}$ futebol seria uma extensão ou quem sabe a concretização desse imaginário. O que não se deve fazer, no entanto, é romantizar estes estilos, esquecendo-se que nele há conflitos, fluxos de poder e violências como em outros contextos (Damo, 2005, p. 147).

Os efeitos extracientíficos desse tipo de observação, conforme já assinalei em minha tese (Souza, 2014), são questionáveis e alvo potencial de indagação para qualquer adepto de uma perspectiva teórica mais crítica. No entanto, o que interessa sublinhar desse relato é que a matriz futebolística 126 aludida no texto - matriz na qual prevalece a informalidade e o improviso -, vai ao encontro daqueles atributos estéticos reconhecidos no mundo social como inerentes ao "estilo futebolístico brasileiro", ou seja, ao denominado "futebol-arte". A primeira conclusão que se extrai, portanto, é que esse "estilo", além de existir objetivamente, permearia uma prática a princípio "desinteressada" do futebol na esfera do lazer.

A segunda conclusão passível de ser visualizada nesse relato de Damo é que a "arte" atribuída aos brasileiros de "contornarem o incontornável" seja com "a bola nos pés" ou então em seus "cotidianos intensos e dramáticos" a partir de um "jeitinho tendencialmente próprio", também é acionada para praticar o futebol bricolado. A meu ver, essa leitura acaba estabelecendo uma relação de "causa-efeito" entre uma suposta conduta ética e uma suposta conduta estética do brasileiro na prática do futebol. Ao denotar esse tipo de conexão, a proposta se reconcilia com uma tradição intelectual que faz da busca pelas singularidades brasileiras 
a "pedra angular" de suas reflexões e, no caso do futebol, reivindica, em primeiro lugar, uma explicação para o significado social dessa prática a partir dos "estilos de jogo" e, em segundo lugar, uma leitura com base na crença desse lócus como espaço para vivência, ainda que provisória, da democracia. Observe-se como a tradição damattiana ganha contornos reestilizados na argumentação de Damo:

O Gre-Nal, por exemplo, é uma "aula de democracia", sem dúvidas. Quando o Inter vence, vencem todos os colorados e, vale recordar, há entre eles pessoas de todas as classes sociais. Ou será que quando o Grêmio ganha apenas a elite comemora? Não, a vitória é de todos os gremistas, inclusive dos negros que a ele pertencem. O que faz do Gre-Nal uma "aula de democracia”, e diga-se de passagem, absorvente, são os cânticos, xingamentos e outras tantas manifestações que permitem expressar, coletivamente, determinados sentimentos acerca do "outro". Talvez porque não existam outros fóruns para tal, ou porque tais sentimentos tenham de ser expressos de uma maneira tal que só o futebol permite, à medida que faz a "seriedade" passar-se por "brincadeira" (Damo, 1998, pp. 230-231).

Por não romper radicalmente com a interpretação damattiana, Damo é levado a analisar aquilo que se associa muito mais ao domínio de uma violência simbólica no futebol gaúcho e brasileiro a partir de uma lente antropológica aparentemente "positiva" e "neutra", atenta muito mais ao discurso politicamente correto da alteridade e da diversidade do que ao desvelamento crítico dessas relações. Além disso, ao considerar que o futebol, ainda que não à maneira originalmente prevista por DaMatta, se constitui em uma "aula de democracia”, Damo acaba por circunscrever essa prática no âmago dos chamados ritos de inversão, onde o mundo pode então ser celebrado de "cabeça para baixo". 
A dimensão de consenso outra vez prevalece, e o futebol passa a ser visto como espaço que fornece uma liberdade de expressão e de dizer coletivamente o que os indivíduos pensam a respeito dos outros, o que se assemelha em muito com a totalização da experiência da democracia em DaMatta. Mas, até aí, nenhum problema, considerando as múltiplas e legítimas possibilidades de explicar o mundo social.

Do ponto de vista da sociologia do conhecimento, o elemento complicador e motivo de uma análise crítica mais circunstanciada é que essas ideias partilhadas pela linhagem culturalista informam a realidade, e não apenas a capturam ou retratam. Aliás, o efeito subversivo do poder simbólico dessa linhagem em trazer à existência a coisa nomeada por meio de ritos de instituição (Bourdieu, 1998) é ainda maximizado pelo fato dessas ideias "caírem" no campo dos especialistas do marketing, legitimando a partir do mercado essa ou qualquer outra visão hegemônica de mundo. Uma pro128 paganda da Mastercard referente à Copa de 2002, veiculada na edição especial da revista Veja de julho daquele ano ilustra bem o que aqui estou argumentando: "Molecagem em 58: uma estrela; ginga em 62: duas estrelas; futebol-arte em 70: três estrelas; raça em 94: quatro estrelas; ter uma seleção cinco estrelas: não tem preço"

É imperativo ressaltar que essas ideias não são um presente dos céus. Antes, foram originalmente tecidas pelos intelectuais e, por via do mercado e do trabalho dos especialistas culturais, se espalharam para a sociedade como um todo. A noção de "futebol-arte", apanágio e sustentáculo da identidade brasileira, é um exemplo elucidativo disso. Pensada pioneiramente por Freyre, acionada em Mário Filho, sistematizada em DaMatta e empregada como categoria analítica por vários dos estudiosos atuais do futebol, essa noção ganhou o "coração" dos brasileiros através de

1 Propaganda da Mastercard na edição n. 1578a de 2002 da revista Veja, p. 37. 
sua exposição constante no campo midiático e nas demais esferas de produção e circulação cultural no país.

No cenário futebolístico recente, o suporte palpável e tangível desse investimento que consiste em descobrir os genes do "futebol-arte" nacional encontra-se em Neymar, revelado pelo Santos Futebol Clube e jogador da seleção brasileira. Em outros tempos não tão remotos, os "suportes" desses signos foram jogadores como Robinho, Ronaldinho Gaúcho, Ronaldo, Romário, Zico e, de modo um tanto paradigmático, Sócrates, como é possível notar na propaganda da Coca-Cola divulgada na revista Veja em maio de 1993:

Calcanhar (Do Bras. dar de calcanhar) s. m. 1. Lance artístico do futebol, em que o jogador que tem a bola entre os pés surpreende seu adversário passando-a, inesperadamente, para um companheiro de equipe, com um toque sutil de calcanhar. Esta jogada de classe, que pipoca a torto e a direito nos campos de futebol no Brasil, foi aperfeiçoada pelo jogador Sócrates. O "doutor Sócrates”, como era conhecido, lançava a bola com ambos os calcanhares, confundindo seus marcadores que ficavam sem eira nem beira, zonzinhos da silva. Daí surgiu, provavelmente, a expressão "não chega ao nosso calcanhar", referente aos jogadores internacionais que não têm a malícia, a criatividade e o talento dos brasileiros. 2. Parte posterior do pé que passou a ser mais valorizada depois da invenção do lance (1). A Coca-Cola, patrocinadora oficial da seleção brasileira juvenil, júnior, feminina e profissional, acredita e investe no futebol arte, o único no mundo capaz de criar jogadas tão geniais como o calcanhar ${ }^{2}$.

É insofismável a força desse tipo de interpretação que percorre o campo acadêmico, atravessa os campos de produção

2 Propaganda da Coca-Cola na edição n. 1289 de 2002 da revista Veja, p. 60. Grifo meu. 
dos bens culturais, chega ao senso comum e completa seu ciclo de rotatividade sendo devolvida ao campo acadêmico através de pesquisas atentas em desvelar, por um lado, as motivações "conscientes" dos atores e, por outro, em fazer uso reificado das fontes sem um exame crítico e rigoroso. Completado o ciclo, uma nova sequência é posta em movimento e, com isso, o conjunto de ideias vai sendo cotidianamente atualizado no sentido de garantir uma "utilidade social" para o futebol, qual seja a de veicular e reiterar tão eficazmente a identidade nacional.

Nessa trama, vai sendo produzido e cristalizado um sentimento de unidade nacional convergente a certos interesses, ainda que esse agenciamento não seja planejado. Entra década, sai década, e essa leitura culturalista do futebol, ao mobilizar conjuntamente, num sentido de complementaridade, o esforço acadêmico, a produção dos especialistas culturais e o próprio senso comum - que aciona de forma pré-reflexiva ou reflexiva esses códigos -, termina por consti130 tuir as próprias condições sociais necessárias a seu prestígio, visibilidade e, acima de tudo, rotinização. Em outras palavras, o que ocorre com essa linhagem, em uma proporção talvez maior do que nas outras que estudei alhures (Souza, 2014), é um casamento bem-sucedido, e por isso pouco problematizado, entre teoria e senso comum.

Nesses termos, não seria uma suposta natureza em si do futebol ou o uso calculista que políticos ou elites fizeram dele que teriam a predisposição de transformá-lo num produto de caráter ideológico, conforme analisaram, por exemplo, os adeptos da linhagem marxista da sociologia do futebol (Souza e Marchi Júnior, 2017). Em vez disso, a tentativa bem-sucedida de superestimar a dimensão de consenso na sociedade em detrimento da dimensão de conflito, deve-se, dentre outras coisas, e conforme procurei aqui demonstrar, à ênfase analítica conferida aos aspectos nacionalistas e aos elos identitários que supostamente se reinventariam e se atualizariam no país pelo futebol. 


\section{Considerações finais}

A contribuição da linhagem culturalista da sociologia do futebol no projeto de construção histórica da identidade nacional é insofismável. Ao concorrer para que o futebol se conformasse aos ideais de nação vislumbrados pelos principais intérpretes do país, essas pesquisas, de forma naturalizada, constituíram um movimento consensual de preservação e atualização de um "mundo social invertido", com efeitos decisivos no obscurecimento dos "fios" que estruturam as dinâmicas sociais em uma sociedade periférica como a brasileira; uma sociedade que, assim como qualquer outra, fez uso social de passatempos, jogos e, no advento da modernidade, dos esportes.

Assim sendo, se esse mundo "suspenso", "liminar" e "extraordinário" que o futebol institui se levanta de tempo em tempo, ou de semana em semana no Brasil, não é de estranhar que seja habitado por "mocinhos" e "bandidos", por "heróis" e "malandros", e que, além disso, por via de seus porta-vozes da academia ou da mídia, apeteça-lhe ser reconhecido por sua "ginga", sua "arte" e seu estilo "genuinamente" nacional. Em certa medida, e guardadas as particularidades ou mesmo exceções à regra, os estudos culturalistas aqui mencionados, ao materializarem uma série de análises através de um uso crítico ou acrítico de categorias como "futebol dionisíaco", "futebol-arte", "futebol gingado", "futebol moleque”, "pátria de chuteiras", "país do futebol”, "estilo nacional”, "paixão nacional", "jeitinho brasileiro" etc., não apenas concorreram para restituir cientificamente as dinâmicas estruturantes do contexto de ação futebolístico, como pensaram seus proponentes, mas também contribuíram para a preservação das tradições e raízes identitárias dessa prática esportiva no Brasil (Souza, 2014).

Por fim, ressalto que não foi possível explorar todas as particularidades analíticas abertas por essa linhagem, 
embora o mais importante para meu argumento tenha sido exposto, a saber, o fato de que determinados autores, por conta das conclusões mais generalistas de suas pesquisas e das categorias analíticas que evocaram em seus empreendimentos, são os atuais herdeiros da linhagem culturalista da sociologia do futebol em uma lógica de trabalho intelectual que mobiliza, por um lado, uma série de aspectos identitários e emocionais e, por outro, mantêm vivas as ideias de Freyre, Mário Filho e DaMatta. Levados a um nível maior de radicalidade, é possível afirmar que certos estudos contribuem para que seja preservada - por intermédio da influência que o campo acadêmico exerce sobre o debate público nacional - a própria ideia de nation-building brasileira nas relações que cabem ao futebol nesse processo.

\section{Juliano de Souza}

é professor associado do Programa de Pós-Graduação em 132 Educação Física da Universidade Estadual de Maringá e da Universidade Estadual de Londrina (PPGEF-UEM/UEL).

\section{Bibliografia}

BARRETO, Túlio Velho. 2004. Freyre e o futebol-arte. Revista da USP, n. 62, pp. 233-238.

BOURDIEU, Pierre. 1989. O poder simbólico. Tradução de Fernando Tomaz. Lisboa: Difel. 1998. A economia das trocas lingüisticas: o que falar quer dizer. Tradução de Sérgio Miceli et al. 2. ed. São Paulo: Edusp.

BRANDÃO, Gildo Marçal. 2005. Linhagens do pensamento político brasileiro. Dados: Revista de Ciências Sociais, v. 48, n. 2, pp. 231-269.

CAPRARO, André Mendes. 2011a. O futebol na obra de um ensaísta: Gilberto Freyre e o ideal da integração racial. Revista da Educação Física da UEM, v. 22, n. 1, pp. 139-149. 2011b. Mário Filho e a "invenção" do jornalismo esportivo profissional. Movimento, v. 17, n. 2, pp. 213-224.

CARDOSO, Fernando Henrique. 1962. Capitalismo e escravidão no Brasil meridional: o negro na sociedade escravocrata do Rio Grande do Sul. São Paulo: Difel. 
2006. Um livro perene. In: FREYRE, Gilberto. Casa-grande $\mathcal{E}^{2}$ senzala: formação da família brasileira sob o regime da economia patriarcal. 51. ed. São Paulo: Global, pp. 19-28.

DAMATTA, Roberto. 1982a. Esporte na sociedade: um ensaio sobre o futebol brasileiro. In: . (org.). Universo do futebol: esporte e sociedade brasileira. Rio de Janeiro: Pinakotheke, pp. 19-42.

. 1982b. Futebol: ópio do povo versus drama de justiça social. Novos Estudos Cebrap, v. 1, n. 4, pp. 54-60.

1997. Carnavais, malandros e heróis: para uma sociologia do dilema brasileiro. 6. ed. Rio de Janeiro: Rocco.

2003. Em torno da dialética entre igualdade e hierarquia: notas sobre as imagens e representações dos Jogos Olímpicos e do futebol no Brasil. Antropolítica, n. 14, pp. 17-39.

2004. O esporte e o jogo como formadores de comportamentos sociais. In: ROSA, Alexandre Machado et al. Esporte e sociedade: ações socioculturais para a cidadania. São Paulo: IMK, pp. 27-48.

2006. A bola corre mais que os homens: duas copas, treze crônicas e três ensaios sobre o futebol. Rio de Janeiro: Rocco.

DAMO, Arlei Sander. 1998. Para o que der e vier: o pertencimento clubístico no futebol brasileiro a partir do Grêmio Foot-Ball Porto Alegrense e seus torcedores. $247 \mathrm{f}$. Dissertação de Mestrado em Antropologia Social. Porto Alegre: UFRGS. 2005. Do dom à profissão: uma etnografia do futebol de espetáculo a partir da formação de jogadores no Brasil e na França. $435 \mathrm{f}$. Tese de Doutorado em Antropologia Social. Porto Alegre: UFRGS.

FAORO, Raymundo. 1979. Os donos do poder: formação do patronato político brasileiro. 3. ed. São Paulo: Globo.

FERNANDES, Florestan. 2008. A integração do negro na sociedade de classes: $o$ legado da "raça branca". 5. ed. São Paulo: Globo. v 2.

FREYRE, Gilberto. 2003a. Sobrados e mucambos. 2. ed. São Paulo: Global. 2003b. Prefácio à $1^{\text {a }}$ edição. In: RODRIGUES FILHO, Mário. $O$ negro no futebol brasileiro. 4. ed. Rio de Janeiro: Mauad, pp. 24-26. 2006. Casa-grande Ẽ senzala: formação da familia brasileira sob o regime da economia patriarcal. 51. ed. São Paulo: Global.

GUEDES, Simoni Lahud. 2003. Lógicas da emoção. Revista Brasileira de Ciências Sociais, v. 18, n. 51, pp. 179-183.

HOLANDA, Sérgio Buarque. 1979. Tentativas de mitologia. São Paulo: Perspectiva. 1995. Raizes do Brasil. 26. ed. São Paulo: Companhia das Letras.

IANNI, Octávio. 1962. As metamorfoses do escravo: apogeu e crise da escravatura no Brasil meridional. São Paulo: Difel. 
MANNHEIM, Karl. 1967. O problema de uma sociologia do conhecimento. In: MANNHEIM, Karl; MERTON, Robert King; MILLS, Charles Wright. Sociologia do conhecimento. Rio de Janeiro: Zahar, pp. 13-80. 1976. Ideologia e utopia. 3. ed. Rio de Janeiro: Zahar.

MARANHÃO, Tiago. 2006. "Apolíneos e dionisíacos": o papel do futebol no pensamento de Gilberto Freyre a respeito do "povo brasileiro". Análise Social, v. 41, n. 179, pp. 435-450.

MORAIS, Jorge Ventura; RATTON JÚNIOR, José Luiz. 2011. Gilberto Freyre e o futebol: entre processos sociais gerais e biografias individuais. Revista de Ciências Sociais, v. 42, n. 1, pp. 89-109.

RODRIGUES FILHO, Mário. 2003. O negro no futebol brasileiro. 4. ed. Rio de Janeiro: Mauad.

SOARES, Antonio Jorge. 2003. Futebol brasileiro e sociedade: a interpretação culturalista de Gilberto Freyre. In: ALABARCES, Pablo (org.). Futbologías: fútbol, identidad y violencia en América Latina. Buenos Aires: CLACSO. v. 1, pp. 145-162.

SOUZA, Juliano. 2014. O "esporte das multidões" no Brasil: entre o contexto de ação futebolístico e a negociação mimética dos conflitos sociais. $433 \mathrm{f}$. Tese de Doutorado em Educação Física. Curitiba: UFPR.

134 SOUZA, Juliano; MARCHI JÚNIOR, Wanderlei. 2017. As linhagens da sociologia do futebol brasileiro: um programa de análise. Revista Movimento, v. 23, n. 1, pp. 101-118.

SOUZA, Jessé José. Freire. 2001. A sociologia dual de Roberto DaMatta: descobrindo nossos mistérios ou sistematizando nossos autoenganos? Revista Brasileira de Ciências Sociais, v. 16, n. 45, pp. 47-67. . 2003. A construção social da subcidadania: para uma sociológica política da modernidade periférica. Belo Horizonte: UFMG. . (org.). 2006. A invisibilidade da desigualdade brasileira. Belo Horizonte: UFMG.

TOLEDO, Luiz Henrique. 2000a. Lógicas no futebol: dimensões simbólicas de um esporte nacional. Tese de Doutorado em Antropologia. São Paulo: FFLCH-USP. 2000b. No país do futebol. Rio de Janeiro: Zahar. 2008. Jogo livre: analogias em torno das 17 regras do futebol. Horizontes Antropológicos, v. 14, n. 30, pp. 191-219. 


\section{A LINHAGEM CULTURALISTA DA SOCIOLOGIA DO FUTEBOL BRASILEIRO}

JULIANO DE SOUZA

Resumo: Neste texto procuramos apresentar a linhagem culturalista da sociologia do futebol brasileiro e demonstrar a durabilidade histórica das ideias-força caras a essa "família intelectual”. Também temos por objetivo restituir algumas das relativas particularidades analíticas inerentes a essa linhagem, bem como apontar alguns efeitos sociais da circulação dessas ideias na lógica de reiteração da identidade nacional. O texto foi dividido em três atos: no primeiro, revisitamos, em linhas gerais, o empreendimento fundador de Gilberto Freyre e Mário Filho no tocante à intepretação culturalista do futebol brasileiro; no segundo, recuperamos o modelo teórico de DaMatta e defendemos o caráter sistematizador de suas análises no âmago dessa "família intelectual"; e, no terceiro, fornecemos algumas pistas acerca da rotinização dessa leitura culturalista do futebol no Brasil e de sua repercussão naturalizada nesta sociedade.

Palavras-chave: Sociologia do Futebol; Sociologia do Conhecimento; Brasil.

\section{CULTURALIST LINEAGE OF THE BRAZILIAN SOCCER SOCIOLOGY}

Abstract: In this paper, we seek to present the culturalist lineage of the Brazilian Soccer Sociology and demonstrate the historical endurance of force-ideas crucial to this "intellectual family". We also aim to restore some of the relative analytical peculiarities inherent to this lineage, as well as to point out some social effects of the circulation of these ideas in the logic of national identity reiteration. The text is divided into three acts. In the first, we revisited in general lines the founding enterprise of Gilberto Freyre and Mário Filho 
regarding the culturalist interpretation of Brazilian football; in the second, we recover the theoretical model of DaMatta and defend the systematizing character of its analysis at the heart of this "intellectual family"; and, in the third, we provide some clues on the routinization of this culturalist reading of football in Brazil and its naturalized repercussion in this society.

Keywords: Sociology of Football; Sociology of Knowledge; Brazil.

Recebido: 19/02/2015 Aprovado: 08/12/2017 